BMJ Open

Sport \&

Exercise

Medicine

\section{Objective functional results in patients with knee osteoarthritis submitted to a 2-day educational programme: a prospective randomised clinical trial}

To cite: Rezende MU, Farias FES, Silva CAC, et al. Objective functional results in patients with knee osteoarthritis submitted to a 2-day educational programme: a prospective randomised clinical trial. BMJ Open Sport Exerc Med 2017:2:e000200 doi:10.1136/bmjsem-2016 000200

- Prepublication history and additional material is available. To view please visit the journal (http://dx.doi.org/ 10.1136/bmjsem-2016000200).

Accepted 11 January 2017

CrossMark

Department of Orthopaedics and Traumatology, Faculdade de Medicina, Universidade de São Paulo (FMUSP), São Paulo, Brazil

Correspondence to Dr Marcia Uchoa de Rezende; murezende@uol. com.br

\section{ABSTRACT}

Background: Although education is recommended for the treatment of knee osteoarthritis (KOA), its effectiveness in osteoarthritis $(\mathrm{OA})$ remains low according to subjective questionnaires. The timed-upand-go (TUG) and five-times-sit-to-stand tests (FTSST) reflect muscle strength and balance and could be used as objective measures of effectiveness.

Aim: To measure the effect of an educational programme in patients with KOA by TUG and FTSST and correlate these results to those of subjective questionnaires.

Methods: Prospective randomised controlled trial of patients with KOA. Participants $(n=198)$ were allocated into four groups. Three groups participated in 2 days of lectures with 1 (group 1), 2 (group 2) and 3-month (group 3) intervals between classes. Group 4 had no classes. Participants were asked to exercise at least three times a week. Half of the patients from all groups received bimonthly telephone calls reinforcing diet and exercise instructions. All four groups received the printed and video material presented in the classes. At baseline and at 1 year after initial assessment, patients performed the FTSST and TUG and answered WOMAC Lequesne, SF-36 and Visual Analogue Scale questionnaires.

Results: The TUG results did not change at 1 year follow-up, whereas FTSST improved (average difference of $4.66, p<0.001$ ) irrespective of the implementation of classes or telephone calls. Both baseline and 1 year TUG and FTSST results correlated weakly $(r<0.3)$ to the subjective functional, pain and quality of life results $(p<0.001)$.

Conclusions: This educational programme improved function as determined by lower limb muscle strength (FTSST) irrespective of the patients' subjective nonimprovement.

Trial registration number: Clinical trials registration number: NCT01572051.

Level of evidence: Level $1 \mathrm{~A}$.

\section{INTRODUCTION}

Osteoarthritis (OA) is the most common form of joint disease. It presents a high

\section{What are the new findings?}

- This educational programme about osteoarthritis (OA) led to improved lower limb muscle strength.

- Education of the patient with knee osteoarthritis (KOA) improves their physical function.

- Correlations between muscle strength improvement and hours of exercise and the quality and quantity of training should be investigated in future studies to maintain an objective analysis of the results achieved with the educational programme.

- Patients with KOA must be educated and must aim for physical training to improve physical function.

economic burden due to disability, comorbid diseases, cost of treatment and its high prevalence. ${ }^{1}$ Increased age, obesity, injuries to joint areas, rigorous physical activity, low socioeconomic level, decreased muscle strength and joint stability are important risk factors for OA. ${ }^{2-6}$

The most common site of $\mathrm{OA}$ localisation is the knee joint. ${ }^{7}$ The main treatment for $\mathrm{KOA}$ is based on education, diet and exercise. $^{8-11}$

A 2-day educational programme with lectures and workshops about OA, reinforced by telephone calls, for patients with KOA was created. Its efficacy was compared with that of the distribution of educational material only (supplemented or not with telephone calls).

In the past, the effectiveness of a week-long educational programme about osteoporosis was measured by the incidence of falls and re-fracture. ${ }^{12}$ In this 2-day programme for $\mathrm{KOA}$, the assessment of the degree of functional independence was chosen as a 
measure of effectiveness. Sitting and standing are among the most routinely practised activities in daily living. ${ }^{13}$ Minimum levels of muscle power, coordination, balance $^{14}$ and flexibility ${ }^{15}$ seem to be necessary to accomplish these actions, as well as other daily activities.

The hypothesis tested in this study was that a multiprofessional 2-day educational programme on KOA would improve the function and balance of these patients as observed by the timed-up-and-go (TUG) ${ }^{16} 17$ and by the five-times-sit-to-stand test (FTSST) ${ }^{18}$ Secondarily, we verified whether these objective tests are related to the subjective Western Ontario and McMaster Universities Osteoarthritis Index. (WOMAC) WOMAC, Lequesne index, Visual Analogue Scale (VAS) and SF-36) questionnaires. ${ }^{19-21}$

\section{METHODS}

\section{Design overview}

This study was a pilot prospective randomised controlled trial. Clinical measures of balance, mobility and muscle strength were assessed at baseline and after 1 year. All participants had at least 6 months of typical care for the treatment of KOA. Participants from groups 1, 2 and 3 had two Saturdays of classes (10 hours course each, 1, 2 or 3 months apart, respectively) on OA, including theoretical and practical classes on the importance of exercises. ${ }^{22}{ }^{23}$ Home exercises were taught. Participants from group 4 received educational material only. This prospective trial was conducted under the principles of the Declaration of Helsinki and approved by the Ethics Committee for the Analysis of Research Projects (CAPPesq) under the protocol number 0622/11. Clinical trial registration number: NCT01572051.

\section{Setting and participants}

This study was performed at the Department of Orthopedics and Traumatology in a tertiary hospital in Brazil.

To meet the eligibility criteria, patients should have:

1. met the American College of Rheumatology criteria for $\mathrm{KOA}^{1}$;

2. no rheumatoid arthritis or any other rheumatological disease other than $\mathrm{OA}$;

3 . been receiving usual care for $\mathrm{OA}$ in the past 6 months;

4. been able to understand the procedures and provide informed consent.

The exclusion criteria included not being able to perform the FTSST at inclusion, undergoing surgery (not related to KOA) during the study or any other disease preventing the performance of the tests at reassessment.

At the beginning of the study (January 2012), there were 306 patients being treated for KOA at the Osteometabolic Diseases Group at the Institute of Orthopedics and Traumatology, Hospital das Clinicas, University of São Paulo (figure 1). All patients in our department received the same treatment protocol for more than 6 months prior to

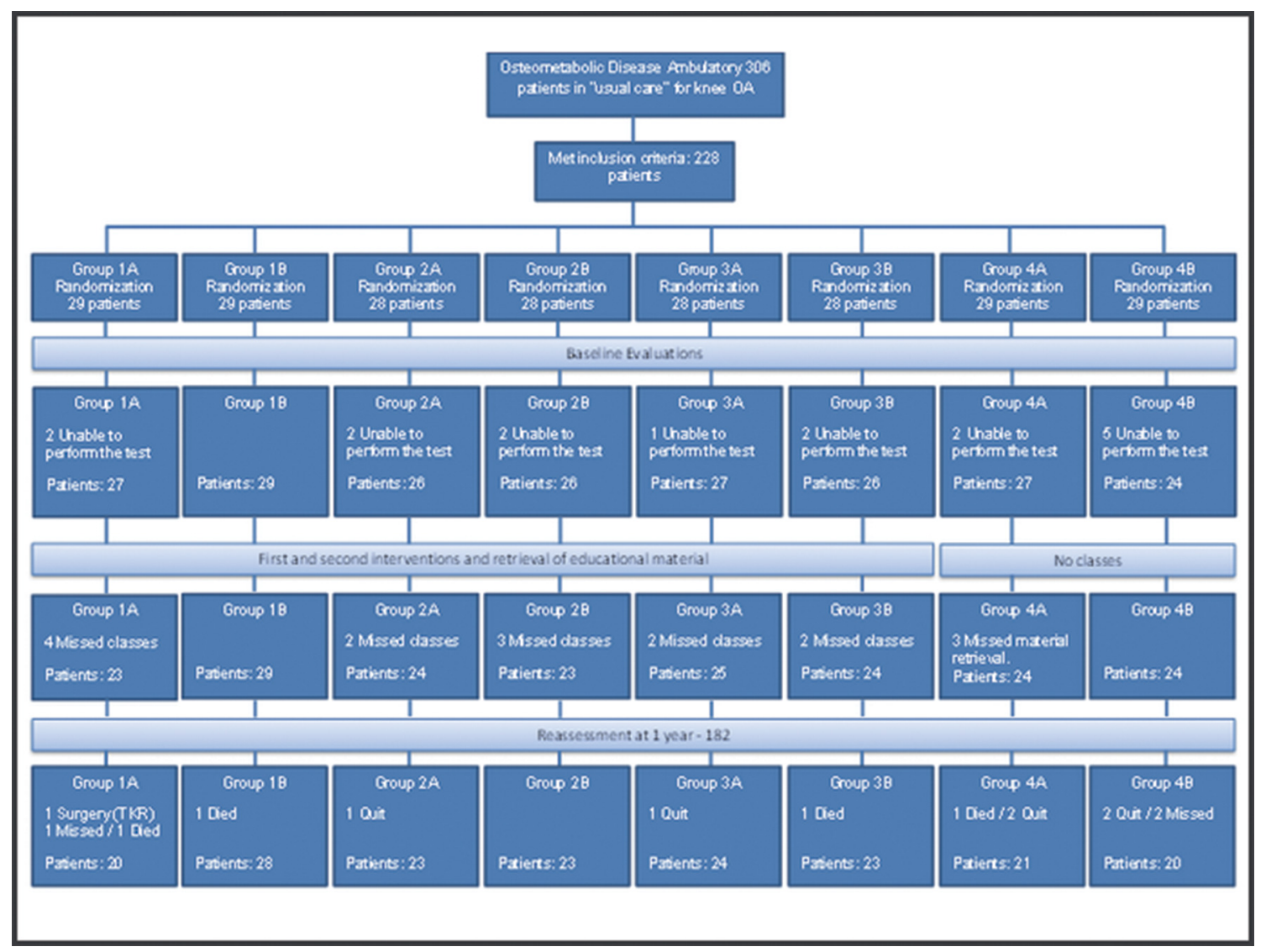

Figure 1 Flow of participants through the trial. 
Table 1 The results of the timed-up-and-go (TUG) and five-times-sit-to-stand (FTSST) tests according to groups, telephone calls and evaluation periods

\begin{tabular}{|c|c|c|c|c|c|c|}
\hline \multirow[b]{2}{*}{ Group } & \multirow[b]{2}{*}{ Calls } & & \multicolumn{2}{|c|}{ TUG } & \multicolumn{2}{|c|}{ FTSST } \\
\hline & & & Baseline & 12 Months & Baseline & 12 Months \\
\hline \multirow[t]{2}{*}{$\begin{array}{l}\text { Two days of lectures } 1 \\
\text { month apart }\end{array}$} & No & $\begin{array}{l}\text { Mean (SD) } \\
95 \% \mathrm{Cl}\end{array}$ & $\begin{array}{l}11(2.8)(9.8 \text { to } \\
12.1)\end{array}$ & $\begin{array}{l}11.4(5.1)(9.3 \\
\text { to } 13.5)\end{array}$ & $\begin{array}{l}21.6(5.4)(19.4 \\
\text { to } 23.9)\end{array}$ & $\begin{array}{l}16.8(4.2)(15 \\
\text { to } 18.5)\end{array}$ \\
\hline & Yes & $\begin{array}{l}\text { Mean (SD) } \\
95 \% \mathrm{Cl}\end{array}$ & $\begin{array}{l}11.8(4.1)(10.1 \\
\text { to } 13.4)\end{array}$ & $\begin{array}{l}12(4)(10.4 \text { to } \\
13.6)\end{array}$ & $\begin{array}{l}23.4 \text { (8.4) (20 to } \\
26.7)\end{array}$ & $\begin{array}{l}19.9(7.3)(17 \\
\text { to } 22.8)\end{array}$ \\
\hline \multirow[t]{2}{*}{$\begin{array}{l}\text { Two days of lectures } 2 \\
\text { months apart }\end{array}$} & No & $\begin{array}{l}\text { Mean (SD) } \\
95 \% \mathrm{Cl}\end{array}$ & $\begin{array}{l}12.8(4.6)(10.9 \\
\text { to } 14.6)\end{array}$ & $\begin{array}{l}11.6(4.2)(9.8 \\
\text { to } 13.3)\end{array}$ & $\begin{array}{l}23.5(6.9)(20.6 \\
\text { to } 26.3)\end{array}$ & $\begin{array}{l}16.6(5)(14.5 \\
\text { to } 18.6)\end{array}$ \\
\hline & Yes & $\begin{array}{l}\text { Mean (SD) } \\
95 \% \mathrm{Cl}\end{array}$ & $\begin{array}{l}11.7(2.7)(10.6 \\
\text { to } 12.9)\end{array}$ & $\begin{array}{l}12.2(3.4)(10.8 \\
\text { to } 13.6)\end{array}$ & $\begin{array}{l}23.6(5.6)(21.3 \\
\text { to } 25.9)\end{array}$ & $\begin{array}{l}18.7(4.7)(16.7 \\
\text { to } 20.6)\end{array}$ \\
\hline \multirow[t]{2}{*}{$\begin{array}{l}\text { Two days of lectures } 3 \\
\text { months apart }\end{array}$} & No & $\begin{array}{l}\text { Mean (SD) } \\
95 \% \mathrm{Cl}\end{array}$ & $\begin{array}{l}13.3(6.7)(10.9 \\
\text { to } 15.8)\end{array}$ & $\begin{array}{l}13.6(5.6)(11.6 \\
\text { to } 15.7)\end{array}$ & $\begin{array}{l}23.2(11.4) \\
\text { (18.9 to } 27.4)\end{array}$ & $\begin{array}{l}17.7(6.7)(15.2 \\
\text { to } 20.2)\end{array}$ \\
\hline & Yes & $\begin{array}{l}\text { Mean (SD) } \\
95 \% \mathrm{Cl}\end{array}$ & $\begin{array}{l}13.3(4.4)(11.4 \\
\text { to } 15.2)\end{array}$ & $\begin{array}{l}12(3.6)(10.4 \\
\text { to } 13.5)\end{array}$ & $\begin{array}{l}25.2(10.3) \\
\text { (20.7 to 29.7) }\end{array}$ & $\begin{array}{l}19.8(6.5)(16.9 \\
\text { to } 22.6)\end{array}$ \\
\hline \multirow[t]{2}{*}{ Material only } & No & $\begin{array}{l}\text { Mean (SD) } \\
95 \% \mathrm{Cl}\end{array}$ & $\begin{array}{l}14.7(7.6)(11.3 \\
\text { to } 18)\end{array}$ & $\begin{array}{l}12,9(5.7)(10.4 \\
\text { to } 15.4)\end{array}$ & $\begin{array}{l}24.5(14.2) \\
(18.3 \text { to } 30.8)\end{array}$ & $\begin{array}{l}21.8(13.3)(16 \\
\text { to } 27.7)\end{array}$ \\
\hline & Yes & $\begin{array}{l}\text { Mean (SD) } \\
95 \% \mathrm{Cl}\end{array}$ & $\begin{array}{l}12.8(3.6)(11.3 \\
\text { to } 14.4)\end{array}$ & $\begin{array}{l}12.4(3.6)(10.9 \\
\text { to } 13.9)\end{array}$ & $\begin{array}{l}21.6 \text { (7) (18.6 to } \\
24.6)\end{array}$ & $\begin{array}{l}18.2(6)(15.6 \\
\text { to } 20.7)\end{array}$ \\
\hline
\end{tabular}

engaging in this study. Medications included: diacerhein for all patients, paracetamol and codeine according to pain level, vitamin D $1000 \mathrm{IU} /$ day if blood levels of vitamin D were insufficient or deficient and calcium supplements according to diet and age. All patients who had varus or valgus deformities were prescribed insoles and those who needed support were prescribed orthotics. Acupuncture was offered as well as orientation for physical activity. Non-steroidal anti-inflammatory drugs were exceptionally used. All patients were invited to participate in the programme. Two hundred and twenty-eight patients (figure 1) were eligible and agreed to participate in the educational programme. Participants were randomly divided into four groups (group 1 had 2 days of classes 1 month apart; group 2, 2 months apart; group 3, 3 months apart and group 4 had no classes). Informed consent was obtained and all rights of the patients were protected.

The average age of the participants was 65 (range 41-89) years; 49 were men and 149 were women. The average height of participants was $1.61 \mathrm{~m}$ (range 1.431.84 , mode 1.65).

\section{Randomisation and interventions}

Randomisation of the patients who agreed to participate was performed by a computer-generated program (available at http://www.randomization.com/). Participants were informed of their groups and dates to come to the hospital. Participants and professionals were not blinded to groups.
All participants answered VAS, WOMAC, Lequesne index and SF-36 questionnaires ${ }^{19-21}$ for the assessment of pain, function and quality of life. They were evaluated with $\mathrm{TUG}^{16}{ }^{17}$ and FTSST ${ }^{18}$ (in a standard chair, $45 \mathrm{~cm}$ high, with arms folded across the chest) by the physical therapy team at baseline and at 1-year reassessment.

Participants from groups 1 to 3 were asked to come to the hospital on two specific Saturdays according to the intervals of each group for an educational programme called PARQVE (Project Arthritis Recovering the Quality of Life by means of Education). ${ }^{22} 23$

Participants were engaged in theoretical lectures with orthopaedic surgeons, psychologists, physiotherapists, occupational therapists, nutritionists, physical educators and social workers. The programme contained basic information about the disease, coping skills, the need for physical activity, exercise guidelines, nutritional correction, the organisation of daily activities and the importance of leisure. They also participated in exercise workshops targeting stretching and muscle strengthening exercises for both the axial and appendicular skeleton. All professionals called their attention to the importance of gaining muscle strength and exercising daily. The physical therapy team showed patients a series of exercises to be performed at least three times a week. Group sessions included less than 29 participants each.

Participants from group 4 came to the hospital during a weekday and retrieved their educational 
Table 2 Analysis of variance results comparing the results of TUG and FTSST between groups, telephone calls and evaluation periods

\begin{tabular}{|c|c|c|c|c|c|}
\hline Variable & Factor & df num & df den & F value & $\mathbf{p}$ \\
\hline \multirow{4}{*}{ TUG } & Moment *group & 3 & 174 & 1.49 & 0.218 \\
\hline & Moment *call & 1 & 174 & 0.42 & 0.516 \\
\hline & Moment *group $*$ call & 3 & 174 & 2.32 & 0.077 \\
\hline & Group *call & 3 & 174 & 0.39 & 0.759 \\
\hline \multirow[t]{4}{*}{ FTSST } & Moment & 1 & 174 & 137.38 & $<0.001$ \\
\hline & Moment *group & 3 & 174 & 2.50 & 0.061 \\
\hline & Call & 1 & 174 & 0.25 & 0.617 \\
\hline & Group *call & 3 & 174 & 1.25 & 0.295 \\
\hline
\end{tabular}

df den, degrees of freedom denominator; df num, degrees of freedom numerator; FTSST, five-times-sit-to-stand test; TUG, timed-upand-go.

material. They were required to watch the digital video disc (DVD) at the hospital and were asked to read and/ or watch the DVD at least two more times at home. If they chose to exercise at home, exercises were available both in the booklet and DVD. Orientations for physical fitness training were given to all patients. Half of the patients from all groups received bimonthly telephone calls reinforcing diet and exercise instructions.

\section{Outcomes and follow-up}

The primary outcome measure was to clinically verify the effectiveness of the educational intervention by the FTSST and TUG at baseline and 1-year reassessment. The secondary outcome was to verify if there was any correlation between the measured results and those obtained by subjective questionnaires. ${ }^{22} 23$

\section{Sample size}

This is a pilot study to evaluate the best (time-wise) intervention to add multi-professional education to KOA clinical treatment. The authors aimed to have 30 patients in each group.

\section{Statistical analysis}

The results of the physiotherapy tests were described according to groups, telephone calls and moments of evaluation with the use of summary measures (mean, SD and 95\% CI). The values between groups, telephone calls and time points were compared with analysis of variance with repeated measures with three factors, followed by Bonferroni multiple comparisons to compare the groups, telephone calls and time points when necessary.

Pearson's correlations were calculated between the functional scales and physiotherapy tests at baseline, 1year reassessment and between changes (of scores and tests) during the follow-up period.

The tests were performed at the $5 \%$ significance level.

\section{RESULTS}

Recruitment began in late January 2012. Interventions began in late February 2012. Of the 228 patients who met the inclusion criteria, agreed to participate and were randomised, 16 were excluded because they were not able to perform TUG and/or FTSST, and 30 were

Table 3 Multiple comparison results for five-times-sit-to-stand test between evaluation periods

\begin{tabular}{|c|c|c|c|c|c|c|}
\hline \multirow[b]{2}{*}{ Comparison } & \multirow[b]{2}{*}{ Mean difference } & \multirow[b]{2}{*}{ SE } & \multirow[b]{2}{*}{ df } & \multirow[b]{2}{*}{$\mathbf{p}$} & \multicolumn{2}{|c|}{$95 \% \mathrm{Cl}$} \\
\hline & & & & & Low & Upper \\
\hline Baseline-12 months & 4.66 & 0.36 & 1 & $<0.001$ & 3.95 & 5.36 \\
\hline
\end{tabular}

$\mathrm{df}$, degrees of freedom. 


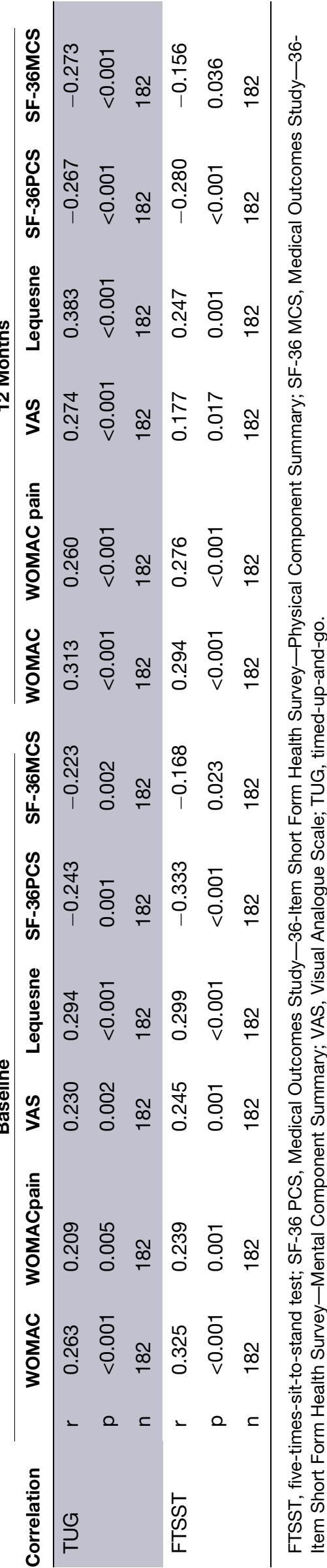

lost to follow-up. Among the 30, 16 missed classes or failed to retrieve the educational material because of loss of interest, distance from the hospital or the inability to come to the hospital on the set date. Four participants died between baseline and reassessment. Six patients quit and three participants missed the 1year reassessment. One patient underwent total knee replacement (figure 1 ).

The results of the TUG and FTSST at baseline and 1-year reassessment are presented in table 1. All groups had similar TUG and FTSST initially and at follow-up. All groups improved FTSST at reassessment (average $4.7 \mathrm{~s}$, CI 3.95 to $5.36, \mathrm{p}<0.001$, tables 2 and 3 ).

Table 4 shows the statistically significant direct correlation of baseline TUG and FTSST with the WOMAC, WOMAC pain, VAS and Lequesne scores $(r>0$ and $p<0.05$ ), and there were inverse correlations between physical therapy tests and the quality of life scales $(p<0, p<0.05)$; specifically, the longer it took to perform the test (higher values of TUG and FTSST) the lower the quality of life. However, although the correlations were significant, almost all showed values in the lower module to $0.3(\mathrm{r}<0.3)$, which represented weak correlations. Similar results were obtained from these correlations at 1-year reassessment (see table 4).

Table 5 shows the lack of correlation between changes in TUG and FTSST with changes in WOMAC, WOMAC pain, VAS, Lequesne and SF-36 scores $(\mathrm{p}>0.05)$.

There were no adverse events.

\section{DISCUSSION}

PARQVE is an educational programme that seeks to improve patients' awareness of the disease and its management and subsequently improve pain, function and quality of life of patients with KOA (associated or not with multiple OA) with or without comorbidities. As mentioned previously, the institution had a positive prior experience with a week-long educational programme in osteoporosis ${ }^{12}$; however, the programme was terminated mainly because of the tertiary/quaternary nature of the hospital. However, the facilities of the hospital are vacant on the weekends, and the need to develop an educational programme in $\mathrm{KOA}$ as a basis for a future OA educational and assistance programme in the primary care setting has become urgent due to Brazil's increasing longevity, obesity level, as well as low education level and socioeconomic status. $^{24-26}$

This pilot study ${ }^{22}$ sought to implement an educational programme for KOA patients. Participants in three groups were required to come to our hospital twice (in 1-month, 2-month or 3-month intervals) to interact with our multi-professional team on the subject of OA. Patients from group 4 came to the hospital during a weekday and retrieved their educational material. They were obliged to watch the DVD at the 
Table 5 Correlations of changes in performance measures (TUG and FTSST) and changes in pain, function and quality of life scores

\begin{tabular}{llllllll}
\hline \multicolumn{1}{c}{ Correlation } & & WOMAC & WOMACpain & VAS & Lequesne & SF-36PCS & SF-36MCS \\
\hline TUG (baseline - 12 months) & $\mathrm{r}$ & 0.059 & 0.063 & 0.039 & -0.013 & -0.019 & 0.050 \\
& $\mathrm{p}$ & 0.432 & 0.398 & 0.598 & 0.865 & 0.799 & 0.502 \\
& $\mathrm{n}$ & 182 & 182 & 182 & 182 & 182 & 182 \\
FTSST (baseline - 12 months) & $\mathrm{r}$ & 0.059 & 0.063 & 0.039 & -0.013 & -0.019 & 0.050 \\
& $\mathrm{p}$ & 0.432 & 0.398 & 0.598 & 0.865 & 0.799 & 0.502 \\
& $\mathrm{n}$ & 182 & 182 & 182 & 182 & 182 & 182 \\
& & & & & &
\end{tabular}

FTSST, five-times-sit-to-stand test; SF-36 PCS, Medical Outcomes Study-36-Item Short Form Health Survey-Physical Component Summary; SF-36 MCS, Medical Outcomes Study-36-Item Short Form Health Survey-Mental Component Summary; TUG, timed-up-andgo; VAS, Visual Analogue Scale.

hospital and were asked to read the booklet and/or watch the DVD at least two more times at home. Considering their low level of education and their difficulties in answering questionnaires or assigning scores to pain, ${ }^{27}$ our main objective was to evaluate the effect of the project on their lower limb muscle strength and balance according to TUG and FTSST. ${ }^{16-18} 28-33$

All groups, irrespective of classes and telephone calls, improved inferior limb muscle strength according to FTSST $^{18} 32{ }^{33}$ at 1 -year reassessment. The height of our chairs was $45 \mathrm{~cm}$ and our patients averaged $1.61 \mathrm{~m}$ in height, so on average, they performed the test close to $100 \%$ knee height with arms folded. ${ }^{33}$ Our patients, both at baseline and at 1-year evaluation, performed the test slower than elderly women ${ }^{33}$ but similar to patients with OA of the hip and/or knee. ${ }^{32}$ TUG results did not improve significantly, but they were on average less than the cut-off values (13 to 16 s) to predict falls in community-dwelling elderly people. ${ }^{31} 3435$ Both TUG and FTSST results had significant but weak correlations with WOMAC, WOMAC pain, VAS, Lequesne and SF-36 at baseline and at reassessment. FTSST showed a significant and moderate correlation with WOMAC pain, stiffness and function. ${ }^{32}$ Our weaker correlation coefficient may have been due to a larger sample or to the particular characteristics of our population, although we did not find the education level to intervene with the completion of the WOMAC questionnaire and mental SF-36 as we did for the VAS, Lequesne and physical component of SF- $36 .{ }^{27}$ No correlations were found between the improvements in FTSST and changes in any of the questionnaires $(\mathrm{p}>0.005)$.

The strengths of the study include the development of a 2-day educational programme about $\mathrm{OA}$ and its prospective randomised design, objective evaluation and the number of subjects. ${ }^{31-39}$ Weaknesses lie in the inability to identify the correlation of functional results with weekly hours of physical activity, comorbidities and the educational level of our participants, which have been shown to intervene in the completion of questionnaires such as Lequesne, SF-36 and VAS. ${ }^{27}$ Although educational level has not been shown to intervene in WOMAC completion, ${ }^{27}$ the improvements observed in the FTSST were not parallel with improvements in the WOMAC. We only correlated FTSST with WOMAC pain and WOMAC total (not with WOMAC stiffness or function), ${ }^{32}$ and this may also explain the weak relationship found in our study and the lack of correlation between improvements in FTSST and WOMAC.

Acknowledgements This study could not have been performed without the voluntary help of Paulo Dallari, Miriam Damaris Di Maio, Heloísa Ungaro, Alípio Jose Gusmão dos Santos, and Pérola Grinberg Plapler; the secretaries (especially Suellen Lima, Natalia Borges, Marlene Deza Blanco, Mislene Oliveira Gonçalves, Rosilane Zaranelli Castro Dutra and Mercedes Alves Coutinho); the occupational therapist team; the social workers; the physical therapists; the psychologists; the physical educators; and the security staff of Hospital das Clínicas, Department of Orthopaedics, Faculdade de Medicina Universidade de São Paulo.

Contributors MUR contributed to the study design, data collection, analysis and manuscript writing and editing. FESF, CACS, CHAC contributed to study design, data collection and manuscript writing. OPC contributed to study design and manuscript editing.

Funding This study was funded by both TRB Pharma TM-Brazil and the Department of Orthopedics and Traumatology, Hospital das Clínicas, University of São Paulo.

Competing interests None declared.

Ethics approval This prospective trial was approved by the Ethics Committee for the Analysis of Research Projects (CAPPesq) under the protocol number 0622/11. Clinical Trials registration number: NCT01572051.

Provenance and peer review Not commissioned; internally peer reviewed.

Open Access This is an Open Access article distributed in accordance with the Creative Commons Attribution Non Commercial (CC BY-NC 4.0) license, which permits others to distribute, remix, adapt, build upon this work noncommercially, and license their derivative works on different terms, provided the original work is properly cited and the use is non-commercial. See: http:// creativecommons.org/licenses/by-nc/4.0/

(C) Article author(s) (or their employer(s) unless otherwise stated in the text of the article) 2017. All rights reserved. No commercial use is permitted unless otherwise expressly granted. 


\section{REFERENCES}

1. Bitton R. The economic burden of osteoarthritis. Am J Manag Care 2009;15:S230-5.

2. Cooper $\mathrm{C}$, Inskip $\mathrm{H}$, Croft $\mathrm{P}$, et al. Individual risk factors for hip osteoarthritis: obesity, hip injury, and physical activity. Am J Epidemiol 1998;147:516-22.

3. Blagojevic M, Jinks C, Jeffery $A$, et al. Risk factors for onset of osteoarthritis of the knee in older adults: a systematic review and meta-analysis. Osteoarthritis Cartilage 2010;18:24-33.

4. Jørgensen KT, Pedersen BV, Nielsen NM, et al. Socio-demographic factors, reproductive history and risk of osteoarthritis in a cohort of 4.6 million Danish women and men. Osteoarthritis Cartilage 2011;19:1176-82.

5. Dekker J, van Dijk GM, Veenhof C. Risk factors for functional decline in osteoarthritis of the hip or knee. Curr Opin Rheumatol 2009;21:520-4.

6. Dunlop DD, Semanik P, Song J, et al. Risk factors for functional decline in older adults with arthritis. Arthritis Rheum 2005;52:1274-82.

7. Pereira D, Peleteiro B, Araújo J, et al. The effect of osteoarthritis definition on prevalence and incidence estimates: a systematic review. Osteoarthritis Cartilage 2011;19:1270-85.

8. Zhang W, Moskowitz RW, Nuki G, et al. OARSI recommendations for the management of hip and knee osteoarthritis, Part II: OARSI evidence-based, expert consensus guidelines. Osteoarthritis Cartilage 2008;16:137-62.

9. Zhang W, Nuki G, Moskowitz RW, et al. OARSI recommendations for the management of hip and knee osteoarthritis: part III: Changes in evidence following systematic cumulative update of research published through January 2009. Osteoarthritis Cartilage 2010;18:476-99.

10. Bruyère $\mathrm{O}$, Cooper $\mathrm{C}$, Pelletier JP, et al. An algorithm recommendation for the management of knee osteoarthritis in Europe and internationally: a report from a task force of the European Society for Clinical and Economic Aspects of Osteoporosis and Osteoarthritis (ESCEO). Semin Arthritis Rheum 2014;44:253-63.

11. McAlindon TE, Bannuru RR, Sullivan MC, et al. OARSI guidelines for the non-surgical management of knee osteoarthritis. Osteoarthritis Cartilage 2014;22:363-88.

12. Plapler PG, Saron TRP, Rezende MU. Education and physical activity in osteoporosis. J Osteopor Phys Act 2014;2:2

13. Roorda LD, Roebroeck ME, Lankhorst GJ, et al. Measuring functional limitations in rising and sitting down: development of a questionnaire. Arch Phys Med Rehabil 1996;77:663-9.

14. Riley PO, Krebs DE, Popat RA. Biomechanical analysis of failed sitto-stand. IEEE Trans Rehabil Eng 1997;5:353-9.

15. Pollock ML, Gaesser GA, Butcher J, et al. American college of sports medicine position stand. the recommended quantity and quality of exercise for developing and maintaining cardiorespiratory and muscular fitness, and flexibility in healthy adults. Med Sci Sports Exerc 1998;30:975-91.

16. Mathias S, Nayak US, Isaacs B. Balance in elderly patients: the 'getup and go' test. Arch Phys Med Rehabil 1986;67:387-9.

17. Podsiadlo D, Richardson S. The timed 'Up \& Go' : a test of basic functional mobility for frail elderly persons. J Am Geriatr Soc 1991;39:142-8.

18. Whitney SL, Wrisley DM, Marchetti GF, et al. Clinical measurement of sit-to-stand performance in people with balance disorders: validity of data for the Five-Times-Sit-to-Stand test. Phys Ther 2005;85:1034-45

19. Bellamy N, Buchanan WW, Goldsmith $\mathrm{CH}$, et al. Validation study of WOMAC: a health status instrument for measuring clinically important patient relevant outcomes to antirheumatic drug therapy in patients with osteoarthritis of the hip or knee. J Rheumatol 1988; 15:1833-40.

20. Lequesne MG. The algofunctional indices for hip and knee osteoarthritis. J Rheumatol 1997;24:779-81.
21. McHorney CA, Ware JE, Raczek AE. The MOS 36-Item Short-Form Health Survey (SF-36): II. Psychometric and clinical tests of validity in measuring physical and mental health constructs. Med Care 1993;31:247-263.

22. de Rezende MU, Campos GC, Pailo AF, et al. PARQVE-Project Arthritis recovering Quality of Life by Means of Education Short-term Outcome in a randomized clinical Trial. J Arthritis 2013;02:1.

23. Rezende MU, Hissadomi MI, Campos GC, et al. One-Year results of an educational program on osteoarthritis: A prospective randomized controlled trial in Brazil. Geriatr Orthop Surg Rehabil 2016;7:86-94.

24. Brasil. Instituto brasileiro de geografia e estatística. Censo demográfico 2010: resultados Gerais da amostra. Rio de Janeiro: IBGE; 2010. http://biblioteca.ibge.gov.br/visualizacao/periodicos/99/ cd_2010_resultados_gerais_amostra.pdf. (accessed in 2016).

25. Brasil. Instituto Brasileiro de Geografia e Estatística: Dados preliminares do Censo 2010 já revelam mudanças na pirâmide etária brasileira. http://saladeimprensa.ibge.gov.br/noticias?view=noticia\&id=1\&idnoticia=1722 \&busca=1\&t=dados-preliminares-censo2010-ja-revelam-mudancas-piramide- etária-brasileira. (accessed in 2016).

26. Brasil. Instituto Brasileiro de Geografia e Estatística. POF 2008-2009 Desnutriçâo cai e peso das crianças brasileiras ultrapassa padrâo internacional. www.ibge.gov.br/home/presidencia/noticias/noticia visualiza.php?id_noticia=1699\&id_pagina=1. (accessed in 2016).

27. Campos GC, Kohara MT, Rezende MU, et al. Schooling of the patients and clinical application of questionnaires in osteoarthitis. Acta Ortop Bras 2014;22:256-9.

28. Shumway-Cook A, Brauer S, Woollacott M. Predicting the probability for falls in community-dwelling older adults using the timed up \& go test. Phys Ther 2000;80:896-903.

29. Steffen TM, Hacker TA, Mollinger L. Age- and gender-related test performance in community-dwelling elderly people: Six-minute walk test, Berg Balance Scale, Timed Up \& Go Test, and gait speeds. Phys Ther 2002;82:128-37.

30. Maly MR, Costigan PA, Olney SJ. Contribution of psychosocial and mechanical variables to physical performance measures in knee osteoarthritis. Phys Ther 2005;85:118-28

31. Nordin E, Rosendahl E, Lundin-Olsson L. Timed 'Up \& Go' test: reliability in older people dependent in activities of daily living-focus on cognitive state. Phys Ther 2006;86:646-55.

32. Lin YC, Davey RC, Cochrane T. Tests for physical function of the elderly with knee and hip osteoarthritis. Scand J Med Sci Sports 2001;11:280-6

33. Ss N, Cheung SY, Lai LS, et al. Five times sit-to-stand test completion times among older women: influence of seat height and arm position. J Rheab Med 2015;47:262-6

34. Okumiya K, Matsubayashi K, Nakamura T, et al. The timed 'up \& go' test is a useful predictor of falls in community-dwelling older people. J Am Geriatr Soc 1998;46:928-9.

35. Dite W, Temple VA. A clinical test of stepping and change of direction to identify multiple falling older adults. Arch Phys Med Rehabil 2002;83:1566-71.

36. Alghadir A, Anwer S, Brismée JM. The reliability and minimal detectable change of timed up and go test in individuals with grade 1-3 knee osteoarthritis. BMC Musculoskelet Disord 2015;16:174.

37. Sabirli F, Paker N, Bugdayci D. The relationship between Knee Injury and Osteoarthritis Outcome Score (KOOS) and timed up and go test in patients with symptomatic knee osteoarthritis. Rheumatol Int 2013;33:2691-4.

38. Wideman $\mathrm{TH}$, Edwards RR, Finan $\mathrm{PH}$, et al. Comparing the predictive value of Task-Performance and Task-Specific sensitivity during physical function testing among people with knee osteoarthritis. J Orthop Sports Phys Ther 2016;21:1-38 .

39. Judd DL, Thomas AC, Dayton MR, et al. Strength and functional deficits in individuals with hip osteoarthritis compared to healthy, older adults. Disabil Rehabil 2014;36:307-12. 